\title{
Patients' and Physicians' Preferences for Approaches to Bone Metastases Treatment in Turkey
}

\author{
Francesca GATTA ${ }^{1}$, Juan Marcos GONZALEZ ${ }^{2}$, Gulnihal ERTUGRUL ${ }^{3}$, Yi QIAN ${ }^{4}$, \\ A Brett HAUBER ${ }^{2}$, Joshua POSNER ${ }^{2}$, Berna OKSUZOGLU ${ }^{5}$, Jorge ARELLANO ${ }^{4}$ \\ ${ }^{1}$ Amgen (Europe) GmbH, Zug, SWITZERLAND \\ ${ }^{2}$ RTI Health Solutions, Research Triangle Park, NC, USA \\ ${ }^{3}$ Amgen Turkey, Istanbul, TURKEY \\ ${ }^{4}$ Amgen Inc., Thousand Oaks, CA, USA \\ ${ }^{5}$ Ankara Oncology Training and Research Hospital, Department of Medical Oncology, Ankara, TURKEY
}

\begin{abstract}
Bone metastases and associated skeletal-related events (SREs) are common in patients with advanced breast, lung, and prostate cancer. Bone-targeted agents (BTAs) are available for the treatment of bone metastases, but little is known about patients' and physicians' preferences for the various attributes of these agents. We evaluated preferences for BTAs used to prevent SREs among patients with bone metastases and physicians involved in treating such patients in Turkey. Participants completed an online discretechoice experiment survey of 10 questions, choosing between pairs of hypothetical treatment profiles, defined by five BTA attributes: time to first SRE, time to worsening of pain, annual risk of osteonecrosis of the jaw (ONJ), annual risk of renal impairment, and administration regimen. The analysis included 91 patients and 99 physicians. Both groups rated annual risk of renal impairment, time to worsening of pain, and time to first SRE as the most important BTA attributes. For patients, the preference weights for all levels of these attributes were significantly different, whereas for physicians, preference weights were significantly different for all levels except time to a 2-point increase in "Brief Pain Inventory" score by 6 months or 10 months. Annual risk of ONJ was judged by patients and physicians to be the least important of the BTA attributes. This study adds to the information available on the preferences of patients and physicians for BTAs and provides useful data to aid clinicians in decision-making by understanding the treatment goals that are important to patients in Turkey.
\end{abstract}

Keywords: Bone-targeted agents, Bone metastases, Discrete-choice experiment, Patient preference, Physician preference, Skeletal-related event

\section{ÖZET}

\section{Türkiye'de Kemik Metastazı Tedavisine Yaklaşımda Hasta ve Hekim Tercihleri}

Kemik metastazları ve bunlardan kaynaklanan iskeletle ilişkili olaylar (ilO) ilerlemiş meme, akciğer ve prostat kanseri olan hastalarda yaygındır. Kemik metastazlarının tedavisi için kemiği hedef alan ilaçlar (BTA'lar) bulunmakla birlikte, hastaların ve hekimlerin bu ilaçların çeșitli özellikleriyle ilgili tercihlerine ilişkin bilgiler sınırıdır. Türkiye'de yapılan bu çalışmada, kemik metastazları olan hastalar ile bu tip hastaların tedavisini yürüten hekimlerin SRE'lerin önlenmesine yönelik BTA'larla ilgili tercihleri değerlendirilmiştir. Katılımcılar çevrimiçi yapılan ve 10 soru içeren çoktan seçmeli deney anketini tamamlayarak beş BTA özelliği ile tanımlanan hipotetik tedavi profili çiftleri arasında seçim yapmıştır: ilk SRE'ye kadar geçen süre, ağrının kötüleşmesine kadar geçen süre, yıllık çene osteonekrozu (ONJ) riski, yıllık böbrek yetmezliği riski ve uygulama rejimi. Analize 91 hasta ve 99 hekim dahil edilmiştir. Her iki grup da yllık böbrek yetmezliği riski, ağıının kötüleşmesine kadar geçen süre ve ilk liO'ya kadar geçen süreyi en önemli BTA özellikleri olarak değerlendirmiştir. 
Hastalar açısından bu özelliklerin tüm düzeylerine ilişkin tercih ağırlıkları anlamlı fark sergilerken, hekimler açısından tercih ağılıkları 6 ay veya 10 aylık "Kısa Ağrı Envanteri" skorunda 2 puanlık artışa kadar geçen süre hariç tüm düzeylerde anlamlı fark sergilemiştir. Hastalar ve hekimler yıllık ONJ riskini BTA'larla ilgili en az önemli özellik olarak değerlendirmiştir. Bu çalışma hastaların ve hekimlerin BTA'lar ile ilgili tercihleri konusundaki bilgileri artırmakta ve klinisyenlerin Türkiye'deki hastalar açısından önemli olan tedavi hedeflerini anlayarak karar vermelerine yardımcı olabilecek yararlı veriler sunmaktadır.

Anahtar Kelimeler: Kemiği hedef alan ilaçlar, Kemik metastazları, Çoktan seçmeli deney, Hasta tercihi, Hekim tercihi, İskeletle ilişkili olay

\section{INTRODUCTION}

Lung, breast and prostate cancers are the most common malignancies among adults in Turkey. According to the World Health Organization, an estimated 24500 new cases of lung cancer, 15200 new cases of breast cancer, and 12700 new cases of prostate cancer were diagnosed in Turkey in 2012. ${ }^{1}$ Bone metastases are common when any of these cancers reach an advanced stage, affecting up to $40 \%$ of patients with advanced lung cancer, up to $75 \%$ of those with advanced breast cancer, and up to $90 \%$ of patients with advanced prostate cancer. ${ }^{2-4}$

Patients with bone metastases from solid tumors often experience bone complications, also known as skeletal-related events (SREs). These are commonly defined as pathologic fracture, radiation to bone, surgery to bone, and spinal cord compression. ${ }^{2}$ Because bone complications are associated with loss of mobility and social functioning, a decrease in quality of life, and a substantial increase in medical costs, ${ }^{5-9}$ the management of these patients is complex and requires a multidisciplinary approach. ${ }^{10}$ In recent years, bone-targeted agents (BTAs) have become a valuable addition to available options for managing bone metastases,${ }^{11}$ which previously included radiotherapy, use of opioids and other systemic therapies. In Turkey, bisphosphonates such as zoledronic acid and the targeted agent denosumab (a RANK ligand inhibitor) are approved for the prevention of SREs among patients with metastatic bone disease from solid tumors.

Well-designed clinical trials have provided evidence of the relative efficacy and safety of BTAs. In particular, denosumab demonstrated superior efficacy in preventing SREs relative to zoledronic acid in patients with bone metastases secondary to solid tumors; however, there are very few studies examining physicians' preferences for BTA attrib- utes (relating to efficacy, safety, mode of administration, etc.). In addition, at a time when the way that physicians treat patients is moving from a disease-centered approach to patient-centered care, more attention is being given not only to patients' awareness of their disease but also to their preferences regarding treatment options and delivery of care. ${ }^{12,13}$

A discrete-choice experiment (DCE), which is a specific conjoint analysis elicitation format to evaluate the importance of different aspects in decision-making, was used to evaluate preferences for attributes corresponding to currently available BTAs. Preferences were elicited among patients with bone metastases from solid tumors and among physicians involved in the care of those patients in Turkey.

\section{MATERIALS AND METHODS}

\section{Study Population}

Patients and physicians were recruited from 111 hospitals (79 research and training hospitals, 23 university hospitals and 9 private hospitals) in the following cities in Turkey: Ankara, Antalya, Istanbul, Izmir, and Samsun. Physicians currently treating patients with bone metastases from solid tumors were eligible to participate and were recruited by an independent agency via a telephone call or faceto-face invitation. Patients aged 18 years or older and residing in Turkey were eligible if they had a self-reported physician diagnosis of bone metastases from any type of solid tumor. Only patients that were able to read and write and complete the questionnaire themselves were recruited. Owing to the low awareness among patients of their disease status (i.e. whether or not they had bone metastases), we asked physicians to identify which of their patients were aware of their bone metastasis status 
and then recruited those individuals via personal invitation. All participants provided informed consent.

\section{Development of the Survey Instrument}

The methodology used for developing the DCE instrument was similar to one previously described. ${ }^{14,15}$ DCEs are a valid and reliable approach for assessing trade-off preferences between different health interventions. ${ }^{16-18}$ In such analyses, the key attributes of a treatment are identified in order to derive preference information between hypothetical treatment options.

A web-enabled DCE was developed and used with physicians during a face-to-face interview. For the patients, however, a pencil-and-paper DCE instrument was used and administered in hospital, ${ }^{19}$ because adults in Turkey, especially elderly individuals, do not routinely use the Internet. ${ }^{20}$ The content of both survey instruments was tested during open-ended interviews with 8 physicians and 15 patients in the United States of America. Before administering the surveys, Turkish translations of the instruments were locally validated in terms of the quality of the translation and for context and relevance.

Both the patient and physician versions of the final DCE instrument contained three sections: 1) screening questions and informed consent; 2) questions on either patients' demographic and clinical characteristics or physicians' demographic characteristics and current level of experience in treating patients with bone metastases; and 3) discrete-choice questions.

To ensure the discrete-choice questions were understandable by patients, the second section of the DCE instrument also provided patients with a written description of each attribute that was illustrated by clinical examples. ${ }^{14}$ The discrete-choice questions in the survey asked patients and physicians to choose between hypothetical treatments based on the treatments' key attributes and the level to which each option fulfilled these attributes. Choices were used to infer preferences for the attributes and attribute levels. Preferences for attributes levels were then used to predict participant's preferences for currently available treatment options.

\begin{tabular}{|c|c|}
\hline Attribute & Levels $^{a}$ \\
\hline $\begin{array}{l}\text { Months until you have a compli- } \\
\text { cation of bone metastases } \\
\text { (Months until first SRE) }\end{array}$ & $\begin{array}{l}28 \text { months } \\
18 \text { months } \\
10 \text { months }\end{array}$ \\
\hline $\begin{array}{l}\text { Months until your pain gets worse } \\
\text { (Months until worsening of pain) }\end{array}$ & $\begin{array}{l}10 \text { months } \\
6 \text { months } \\
3 \text { months }\end{array}$ \\
\hline $\begin{array}{l}\text { Chance of a problem with your } \\
\text { teeth and/or jaw bone each year } \\
\text { because of the medicine } \\
\text { (Annual risk of ONJ) }\end{array}$ & $\begin{array}{l}\text { None } \\
1 \text { out of } 100(1 \%) \\
5 \text { out of } 100(5 \%)\end{array}$ \\
\hline $\begin{array}{l}\text { Chance of kidney damage be- } \\
\text { cause of the medicine each year } \\
\text { (Annual risk of renal impairment) }\end{array}$ & $\begin{array}{l}\text { None } \\
4 \text { out of } 100(4 \%) \\
10 \text { out of } 100(10 \%)\end{array}$ \\
\hline $\begin{array}{l}\text { How you take the medicine } \\
\text { (Administration regimen) }\end{array}$ & $\begin{array}{l}\text { Daily oral tablet } \\
\text { Injection every } 4 \text { weeks } \\
\text { 15-minute infusion } \\
\text { every } 4 \text { weeks } \\
\text { 120-minute infusion } \\
\text { every } 4 \text { weeks }\end{array}$ \\
\hline \multicolumn{2}{|c|}{$\begin{array}{l}\text { a Data used to define the attribute levels were taken from European } \\
\text { Summaries of Product Characteristics and published literature. } \\
\text { BTA= bone-targeted agent; } \mathrm{ONJ}=\text { osteonecrosis of the jaw; } \\
\text { SRE= skeletal-related event. }\end{array}$} \\
\hline
\end{tabular}

According to guidelines on good research practices for DCEs in healthcare, the attributes and attribute levels developed for a survey instrument must be supported by evidence. ${ }^{19}$ After reviewing the prescribing information for currently approved products, searching for published results from clinical trials, and consulting with clinical experts, five attributes were selected to describe the available BTAs (Table 1). For the majority of attributes, three clinically-relevant and well-defined levels were identified, with the exception of mode of administration regimen, for which there were four levels based on current treatment options.

Forty discrete-choice questions were developed, each consisting of a choice between two hypothetical treatment profiles derived from combinations of BTA attribute levels (Table 2), and displayed as "medication A" or "medication B", without referring to the names of any drug (Figure 1 and 2). 
International Journal of Hematology and Oncology

Table 2. Treatment profiles for the BTAs investigated

\begin{tabular}{|c|c|c|c|c|}
\hline \multirow[b]{2}{*}{ BTA attribute } & \multicolumn{4}{|c|}{ Treatment profile } \\
\hline & Denosumab & Zoledronic acid & Clodronate & Pamidronate \\
\hline Time to first SRE & 27.7 months & 19.5 months & $\begin{array}{l}\text { 15-20 months } \\
\text { (assumed } 17.5 \text { months) }\end{array}$ & 10.9 months \\
\hline $\begin{array}{l}\text { Time to a 2-point increase } \\
\text { in pain on the BPI }\end{array}$ & 5.9 months & 5.6 months & 3 months & $\begin{array}{l}\text { Between } 0.03 \text { months } \\
\text { and several months } \\
\text { (assumed } 3 \text { months) }\end{array}$ \\
\hline Risk of ONJ each year & $1.8 \%$ & $1.3 \%$ & $\begin{array}{l}\text { Yes, but value not } \\
\text { stated (assumed } 1 \% \text { ) }\end{array}$ & $\begin{array}{l}\text { Yes, but value not } \\
\text { stated (assumed 1\%) }\end{array}$ \\
\hline $\begin{array}{l}\text { Risk of } 0.5 \mathrm{mg} / \mathrm{dL} \text { increase } \\
\text { in baseline creatinine }\end{array}$ & $0 \%$ & $9.3 \%$ & $\begin{array}{l}\text { Yes, but value not stated } \\
\text { (assumed 5\%) }\end{array}$ & $8.1 \%$ \\
\hline Administration regimen & $\begin{array}{l}\text { Injection every } \\
4 \text { weeks }\end{array}$ & $\begin{array}{l}\text { 15-minute infusion } \\
\text { every } 4 \text { weeks }\end{array}$ & Daily oral tablet & $\begin{array}{l}120 \text {-minute infusion every } \\
4 \text { weeks }\end{array}$ \\
\hline
\end{tabular}

\begin{tabular}{|c|c|c|}
\hline Medication feature & Medication A & Medication B \\
\hline $\begin{array}{l}\text { Months until you have } \\
\text { a complication of bone } \\
\text { metastases }\end{array}$ & 28 months & 18 months \\
\hline $\begin{array}{l}\text { Months until your pain gets } \\
\text { worse }\end{array}$ & 3 months & 6 months \\
\hline $\begin{array}{l}\text { Chance of a problem with } \\
\text { your teeth and/or jaw bone } \\
\text { each year because of the } \\
\text { medicine }\end{array}$ & 5 out of $100(5 \%)$ & None \\
\hline $\begin{array}{l}\text { Chance of kidney damage } \\
\text { because of the medicine } \\
\text { each year }\end{array}$ & 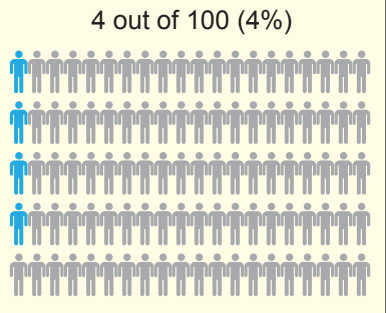 & 10 out of 100 (10\%) \\
\hline How you take the medicine & $\begin{array}{l}\text { 120-minute infusion } \\
\text { every } 4 \text { weeks }\end{array}$ & Injection every 4 weeks \\
\hline Which would you choose? & & \\
\hline
\end{tabular}

Figure 1. Example discrete-choice question (Patients' Questionnaire) 


\begin{tabular}{|c|c|c|}
\hline Medication Feature & Medication A & Medication B \\
\hline Time until first SRE & 28 months & 18 months \\
\hline $\begin{array}{l}\text { Time until a 2-point } \\
\text { increase in pain on the BPI }\end{array}$ & 3 months & 6 months \\
\hline Risk of ONJ each year & 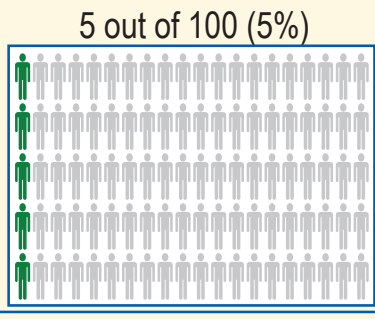 & None \\
\hline $\begin{array}{l}\text { Risk of } 0.5 \mathrm{mg} / \mathrm{dL} \text { increase } \\
\text { in baseline creatinine each } \\
\text { year }\end{array}$ & 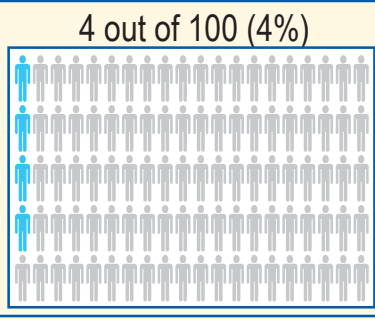 & 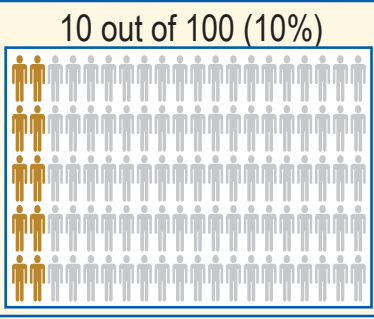 \\
\hline Mode of administration & $\begin{array}{c}\text { 120-minute infusion } \\
\text { every } 4 \text { weeks }\end{array}$ & Injection every 4 weeks \\
\hline $\begin{array}{l}\text { Which would you choose } \\
\text { for Patient } 1 \text { ? }\end{array}$ & 0 & 0 \\
\hline
\end{tabular}

$B P I=$ brief pain inventory; $E R=$ estrogen receptor; $H E R=$ human epidermal growth factor receptor; ONU= osteonecrosis of the jaw; $P R=$ progesterone receptor; $S R E=$ skeletal-related event; TC= docetaxel with cyclophosphamide

Figure 2. Example discrete-choice question (Physicians' Questionnaire)

Patient 1: A 57-year old woman who was diagnosed with breast cancer and developed bone metastases along with $2 \mathrm{~cm}$ mediastinal and supraclavicular adenopathy 3 years after her initial diagnosis. She initially received treatment with docetaxel and cyclophosphamide adjuvant chemotherapy. The tumour is oestrogen receptor/progesterone receptor positive and HER-2 negative. She was on an adjuvant aromatase inhibitor at the time of her relapse. Her recurrence was noted by examination identifying the supraclavicular adenopathy. On further questioning, she admits to increasing mid-back (thoracic area) pain, which she rates as a 4 on a scale of 0 to $10^{*}$. The patient's health is otherwise good (high Karnofsky performance status) with no history of kidney disease and no significant comorbidities.

Or

Patient 2: A 71-year-old man who was initially diagnosed with Gleason 8-10 prostate cancer 3 years ago. He is now castrationresistant and has developed bone metastases. His PSA level is $\geq 10$. He is complaining of left hip pain when he walks and low back pain if he sits too long, which he rates as a 4 on a scale from $0-10^{*}$. The patient's health is otherwise good (high Karnofsky performance status) with no history of kidney disease and no significant comorbidities.

*: Where 0 is no pain and 10 is worst pain imaginable

Peoplegrams (visual representations using images of people to depict the proportion of patients affected by a particular attribute) were used to present the levels of risk of developing osteonecrosis of the jaw (ONJ) and risk of increasing renal impairment. Four versions of the DCE were created, with 10 choice questions each. Physicians were randomly assigned to one of these web-enabled versions, while patients were sequentially assigned to pencil-and-paper versions to control for order effects.

All participants were asked to complete a sample discrete-choice question (Figure 1) before completing the discrete-choice section of the survey instrument. Because physicians see patients at all stages of disease, two patient profiles for what may be considered a typical patient with bone metastases secondary to breast cancer and a typical patient 


\begin{tabular}{|c|c|}
\hline Characteristic & Patient population $(n=91)$ \\
\hline \multicolumn{2}{|l|}{ Gender } \\
\hline Female & $41(45.1)$ \\
\hline Male & $50(54.9)$ \\
\hline \multicolumn{2}{|l|}{ Age (years) } \\
\hline $18-45$ & $14(15.4)$ \\
\hline $46-65$ & $50(55.0)$ \\
\hline$\geq 66$ & $27(29.7)$ \\
\hline \multicolumn{2}{|l|}{ Which of the following complications of bone metastases worries you the most? } \\
\hline A bone fracture & $47(51.6)$ \\
\hline Radiation therapy to prevent a fracture and/or to treat bone pain & $4(4.4)$ \\
\hline Surgery to the bone to prevent a fracture & $6(6.6)$ \\
\hline Increased pressure on the spinal cord & $34(37.4)$ \\
\hline \multicolumn{2}{|l|}{ Type of cancer that led to bone metastases } \\
\hline Breast & $42(46.2)$ \\
\hline Prostate & $19(20.9)$ \\
\hline Lung & $20(22.0)$ \\
\hline Kidney & $10(11.0)$ \\
\hline Less than 2 years since diagnosed with cancer & $57(62.6)$ \\
\hline Less than 1 year since diagnosed with bone metastases & $68(74.7)$ \\
\hline Currently taking treatment for bone metastases & $60(65.9)$ \\
\hline Losing ability to move around affected the patient the most in the past 2 weeks & $36(39.6)$ \\
\hline Had a complication because of bone metastases & $13(14.3)$ \\
\hline \multicolumn{2}{|l|}{ Severity of worst pain in the past week for any reason } \\
\hline No pain & $12(13.2)$ \\
\hline Mild & $13(14.3)$ \\
\hline Moderate & $33(36.3)$ \\
\hline Severe & $33(36.3)$ \\
\hline
\end{tabular}

Data are $\mathrm{n}(\%)$ : percentages exclude missing values.

with bone metastases secondary to prostate cancer were provided (Figure 2) ${ }^{14}$ Physicians were then asked to make hypothetical treatment decisions based on these profiles.

\section{Analyses}

The patterns of physicians' and patients' preferences were analyzed using random-parameters logit (RPL) models, which estimate a preference weight for each attribute level in the study. RPL models avoid potential estimation bias from unobserved preference heterogeneity among participants by estimating a distribution of preferences across participants for each preference parameter. ${ }^{21}$ The distance between the preference weight for the best and worst levels of an attribute can be interpreted as the relative importance of the attribute to the patients' and physicians' treatment choice.

Predicted choice probabilities (PCPs) were calculated using RPL model results to evaluate relative preferences for full treatment profiles. PCPs predict the percentage of participants who would select a treatment profile with particular characteristics. PCPs do not account for market conditions (e.g., real-world available treatment substitutes, limitations in information available to patients). PCPs were estimated for BTA profiles with characteristics similar to denosumab, zoledronic acid, clodronate, and pamidronate. Estimated preferences were based on participants' responses to the 10 choice questions. Drug names and drug information were not provided at any time to the participants. 
Table 4. Physician baseline characteristics

Characteristic

Physician population $(\mathrm{n}=99)$

Age ( years)

26-35 30 (30.3)

$36-45 \quad 36(36.4)$

$\geq 46$

How many years have you been in practice since completing your medical training?

4-9

$19(19.2)$

$\geq 10$

$80(80.8)$

Which of the following describes your practice? (Check all that apply)

Private hospital

$8(8.1)$

State hospital

$5(5.1)$

University hospital

26 (26.3)

Training and research hospital

$62(62.6)$

Private office

$1(1.0)$

Which of the following best describes your area of specialization?

Radiation oncology

$56(56.6)$

Medical oncology

$43(43.4)$

On average, how many patients with bone metastases from solid tumors do you treat each week?

$\leq 10$

$51(52.0)$

$>10$

47 (48.0)

Data are $n(\%)$ : percentages exclude missing values.

\section{RESULTS}

\section{Participant Characteristics}

A total of 94 patients and 101 physicians completed the DCE survey. Three patients and two physicians always chose the same answer, medication $\mathrm{A}$ or medication $\mathrm{B}$, in the choice questions, indicating a lack of attention to the questions, 17 these participants were excluded from the analysis. The final sample included 91 patients and 99 physicians.

More than half of patients (55\%) reported that they were 46-65 years old (Table 3). Breast cancer was the most common malignancy among the patients. Most patients (75\%) had only recently (within the past year) been diagnosed with bone metastases and $66 \%$ were receiving treatment for bone metastases. Approximately $70 \%$ of patients had experienced moderate or severe pain in the week preceding the DCE (Table 3 ). Over $85 \%$ of patients had never experienced dental problems or kidney damage.

Physicians in the sample were specialists in either radiation or medical oncology $(57 \%$ and $43 \%$, respectively) (Table 4). Most physicians (81\%) had
10 or more years of experience in clinical practice and the majority (63\%) worked in a training and research hospital.

\section{Preference Weights for Patients and Physicians}

Patients and physicians were aligned with regard to their preferences for the most important BTA attributes. Annual risk of renal impairment was considered the most important attribute for both groups of participants. While patients believed that the second and third most important attributes were time to worsening of pain and time to first SRE, respectively, these factors were ranked in the reverse order by physicians (Figure 3). For patients, the preference weights for all levels of these attributes were significantly different $(\mathrm{p}<0.05)$, whereas for physicians, the preference weights for all levels of these three attributes were significantly different except for time to a 2-point increase in Brief Pain Inventory score by 6 months or 10 months.

In terms of administration regimen, patients preferred daily oral tablets over injections and infusions, while physicians preferred a 15-minute 
International Journal of Hematology and Oncology

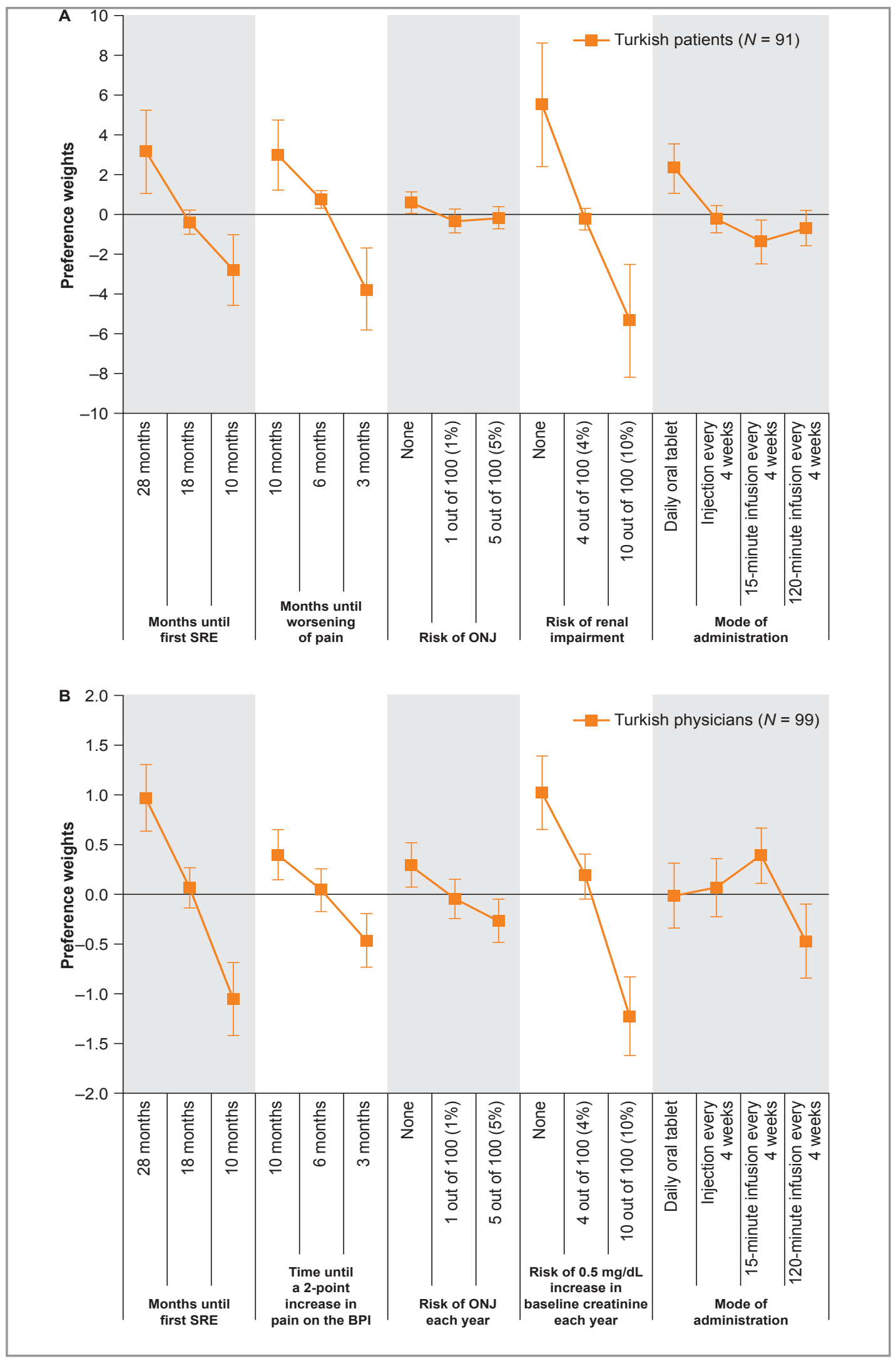

Figure 3. Preference weights for each level of five attributes of the bone-targeting agents investigated. (a) Patients, (b) Physicians 
Table 5. Predicted choice probabilities for treatment profiles with characteristics similar to the bone-targeted agents investigated

\begin{tabular}{|lll|}
\hline Treatment profile & Patients $(\mathbf{n}=\mathbf{9 1})$ & Physicians $(\mathbf{n}=\mathbf{9 9})$ \\
\hline Denosumab & $100.0 \%(99.6-100.0 \%)$ & $85.8 \%(72.6-93.0 \%)$ \\
Zoledronic acid & $0.0 \%(0.0-0.1 \%)$ & $6.8 \%(2.8-14.6 \%)$ \\
Clodronate & $0.0 \%(0.0-0.2 \%)$ & $6.6 \%(3.1-13.2 \%)$ \\
Pamidronate & $0.0 \%(0.0-0.0 \%)$ & $0.8 \%(0.2-2.6 \%)$
\end{tabular}

Data are mean (95\% confidence interval).

infusion every 4 weeks. For both patients and physicians, there was no significant difference between injection and 15-minute infusion ( $\mathrm{p}>0.05)$.

Annual risk of ONJ was judged by patients and physicians to be the least important of the BTA attributes. For both groups, the preference weights for a $1 \%$ risk of ONJ and a $5 \%$ risk of ONJ were not significantly different $(\mathrm{p}>0.05)$, and for patients, these levels were not ordered as expected on the basis of risk rates.

\section{Predicted Choice Probabilities}

The PCPs, which show the percentage of participants who would choose one treatment over another on the basis of their attributes, are presented in Table 5. Using the preference weights from the DCE results, it was predicted that the entire patient sample (100\%; 95\% confidence interval [CI], 99.6$100 \%)$ and the majority of physicians $(86 \% ; 95 \%$ CI, 73-93\%) would prefer a BTA profile with characteristics similar to denosumab (Table 5).

\section{DISCUSSION}

To our knowledge, this is the first study to evaluate the preferences of patients and physicians in Turkey for the various attributes of bone metastases treatments. The three BTA attributes rated as most important by patients and physicians were annual risk of renal impairment, time to worsening of pain, and time to first SRE.

Given the considerable morbidity and mortality associated with SREs, it is unsurprising that time to first SRE was ranked highly by both patients and physicians. However, this attribute was outranked by annual risk of renal impairment by both groups. Renal impairment is common in patients with can- cer, ${ }^{22}$ given the nephrotoxicity of some chemotherapy regimens, the preference for a BTA with a low risk of renal impairment could reflect a desire of patients and physicians to ensure that any treatment for bone metastases does not compromise the use of chemotherapy.

In contrast to patients, the preference weights for physicians for time to an increase in pain by 6 and 10 months did not reach statistical significance. This is interesting in the context of the widespread under-treatment of cancer pain in clinical practice. ${ }^{23,24}$ Notably, in the current study, the majority of patients had experienced moderate or severe pain in the past week. Patients may not communicate their pain to their physician owing to misconceptions about opioid addiction and adverse effects, and their physician's ability to address the problem. ${ }^{25}$ Some patients also under-report pain owing to an acceptance that a certain amount of pain will be experienced during the course of their disease. ${ }^{26}$ Bone pain has a negative effect on quality of life and has been shown to correlate with reduced survival. $^{27,28}$ Therefore, treatment options that prevent or delay the worsening of pain are highly desirable. Annual risk of ONJ was considered the least important BTA attribute by both patients and physicians. Although this is a serious adverse effect of anti-resorptive therapies, preventive dental measures and dental monitoring throughout treatment with a BTA can reduce the risk of ONJ and may have influenced the preferences seen in this study. ${ }^{29}$ Furthermore, only a small proportion (15\%) of patients reported ever experiencing dental problems in the past, which may mean that most patients did not appreciate the morbidity that could be associated with ONJ. 
Patients preferred a once-daily tablet administration regimen. This may reflect a desire of patients to avoid travel to hospitals in order to receive medication or could be due to needle phobia. In contrast, there were no significant differences between the physicians' preferences for administration regimen, although a 15-minute infusion every 4 weeks was the highest ranked option. Physicians may prefer administration options that involve contact with patients. Treatment adherence may also be easier to monitor with injections or infusions than with oral tablets, which are taken outside the hospital.

Two DCEs with similar designs have recently been conducted in other countries. A study of patients and physicians in France, Germany, and the UK also found that time to SRE, risk of renal impairment, and time to worsening of pain were the most important BTA attributes for both patients and physicians. ${ }^{14,15}$ In a study of physicians, patients, caregivers, and nurses in the USA, out-of-pocket cost to patients, time to first SRE, and risk of renal impairment were rated as the most important BTA attributes by each group. ${ }^{30-32}$ These studies confirm that treatments that delay SREs and worsening of pain with a low risk of renal impairment are desirable in the opinions of both patients and physicians across Europe and the USA.

Our data reflect the preferences of patients and physicians in real-world clinical practice. However, DCEs have some limitations; participants are asked to evaluate hypothetical treatment profiles, so responses to questions can differ from treatment decisions in the real-world setting. In addition, the financial implications of the decisions made by patients and physicians were not considered in this study but are likely to influence treatment choices in clinical practice.

Recruiting patients for this study was more challenging than for previous similar DCEs. ${ }^{14,15}$ This was thought to be because of a lack of awareness among patients about their disease status. Although studies show that, in some countries, full disclosure of diagnosis and prognosis by physicians to patients with cancer is increasing, ${ }^{33,34}$ in Turkey there may still be reluctance among physicians, relatives, and caregivers regarding revealing the severity of a condition to the patient. A diagnosis of cancer may be considered as a "death sentence", and therefore patients' relatives and physicians may insist on avoiding discussing the stage of the cancer in detail. ${ }^{13}$ Sharing decision-making between patients and physicians has been shown to have a positive effect on treatment adherence and health outcomes. ${ }^{35,36}$ Therefore, increasing the involvement of patients in treatment decisions in clinical practice is advocated.

In conclusion, when considering treatment choices for preventing bone complications associated with bone metastases from solid tumors, patients and physicians in Turkey focused mainly on the risk of renal impairment, delaying SREs and worsening of pain. The range of ONJ risk levels included in this study did not deter patients and physicians from selecting treatments that could help to delay SREs or pain. This study adds to the information available on the preferences of patients and physicians regarding BTA attributes and provides useful data on the treatment goals that are important to patients in Turkey, which will aid clinicians in decisionmaking. The shared preferences of patients and physicians suggest that a collaborative approach to decision-making is feasible and may be beneficial given the value placed upon treatment options with superior efficacy and safety in terms of risk of renal impairment. This study may also aid payers in deciding which treatment options to reimburse.

\section{Funding}

Funding for this study was obtained from Amgen, Thousand Oaks, California, USA.

\section{Acknowledgments}

Medical writing support was provided by Kim Allcott PhD of Oxford PharmaGenesis Ltd, funded by Amgen (Europe) GmbH. Editorial support was provided by Emma Booth of Amgen (Europe) GmbH.

\section{Conflict of Interest}

RTI Health Solutions, an independent research institution, received funding from Amgen to complete this study. Juan Marcos Gonzalez, Brett Hauber, and Joshua Posner are employees of RTI Health Solutions. Francesca Gatta is an employee 
of Amgen (Europe) GmbH. Gulnihal Ertugrual is an employee of Amgen Turkey and owns stock. Yi Qian and Jorge Arellano are employees of Amgen Inc. and own stock.

\section{REFERENCES}

1. Ferlay J, Soerjomataram I, Ervik M, et al. GLOBOCAN 2012 v1.0, Cancer Incidence and Mortality Worldwide: IARC CancerBase No. 11. Lyon, France: International Agency for Research on Cancer; 2013. http://globocan.iarc.fr. Accessed October 2014.

2. Coleman RE. Clinical features of metastatic bone disease and risk of skeletal morbidity. Clin Cancer Res 12: 6243s-6249s, 2006.

3. Parker C, Nilsson S, Heinrich D, et al. Alpha emitter radium-223 and survival in metastatic prostate cancer. N Engl J Med 369: 213-23, 2013.

4. Coleman RE. Skeletal complications of malignancy. Cancer 80(8 Suppl): 1588-1594, 1997.

5. Broder MS, Gutierrez B, Cherepanov D, Linhares Y. Burden of skeletal-related events in prostate cancer: unmet need in pain improvement. Support Care Cancer 23: 237-247, 2015.

6. Costa L, Badia X, Chow E, et al. Impact of skeletal complications on patients' quality of life, mobility, and functional independence. Support Care Cancer 16: 879-89, 2008.

7. DePuy V, Anstrom KJ, Castel LD, et al. Effects of skeletal morbidities on longitudinal patient-reported outcomes and survival in patients with metastatic prostate cancer. Support Care Cancer 15: 869-876, 2007.

8. Yong $\mathrm{M}$, Jensen $\mathrm{AO}$, Jacobsen JB, et al. Survival in breast cancer patients with bone metastases and skeletal-related events: a population-based cohort study in Denmark (19992007). Breast Cancer Res Treat 129: 495-503, 2011.

9. Weinfurt KP, Li Y, Castel LD, et al. The significance of skeletal-related events for the health-related quality of life of patients with metastatic prostate cancer. Ann Oncol 16: 579584, 2005.

10. Arican A, Bozkurt T, Bozcuk H, et al. A cross-sectional survey of the diagnosis and management of bone metastasis in breast cancer patients in Turkey. Support Care Cancer 22: 2629-2634, 2014.

11. Coleman R, Body JJ, Aapro M, et al. Bone health in cancer patients: ESMO Clinical Practice Guidelines. Ann Oncol 25 Suppl 3: iii124-137, 2014. doi: 10.1093/annonc/mdu103.

12. Bozcuk H, Erdogan V, Eken C, et al. Does awareness of diagnosis make any difference to quality of life? Determinants of emotional functioning in a group of cancer patients in Turkey. Support Care Cancer 10: 51-57, 2002.
13. Turhal NS, Efe B, Gumus M, et al. Patient satisfaction in the outpatients' chemotherapy unit of Marmara University, Istanbul, Turkey: a staff survey. BMC Cancer 2: 30, 2002.

14. Hechmati G, Hauber AB, Arellano J, et al. Patients' preferences for bone metastases treatments in France, Germany and the United Kingdom. Support Care Cancer 23: 21-28, 2015.

15. Qian $Y$, Hechmati G, Mohamed AF, et al. Physicians' Preferences for Bone Metastases Treatments in France, Germany and the United Kingdom, Value in Health 16: A430-A430, 2013.

16. Marshall D, Bridges JF, Hauber B, et al. Conjoint analysis applications in health - how are studies being designed and reported? An update on current practice in the published literature between 2005 and 2008. Patient 3: 249-256, 2010.

17. Hauber AB, Arden NK, Mohamed AF, et al. A discrete-choice experiment of United Kingdom patients' willingness to risk adverse events for improved function and pain control in osteoarthritis. Osteoarthritis Cartilage 21: 289-297, 2013.

18. Mohamed AF, Hauber AB, Neary MP. Patient benefit-risk preferences for targeted agents in the treatment of renal cell carcinoma. Pharmacoeconomics 29: 977-988, 2011.

19. Bridges JF, Hauber AB, Marshall D, et al. Conjoint analysis applications in health - a checklist: a report of the ISPOR Good Research Practices for Conjoint Analysis Task Force. Value Health 14: 403-413, 2011.

20. Urhan UB, Kizilca I. How does internet usage change in Turkey? An assessment on internet users. Ankara, Turkey: TEPAV [Economic Policy Research Foundation of Turkey], 2011. 2011. http://www.tepav.org.tr/upload/files/1297779538-1. How_does_Internet_Usage_Change_in_Turkey.pdf. Accessed November 2014.

21. Train KE. Discrete choice methods with simulation. Cambridge, UK: Cambridge University Press; 2003: 15-85.

22. Aapro M, Launay-Vacher V. Importance of monitoring renal function in patients with cancer. Cancer Treat Rev 38: 23540, 2012.

23. Deandrea S, Montanari M, Moja L, Apolone G. Prevalence of undertreatment in cancer pain. A review of published literature. Ann Oncol 19: 1985-1991, 2008.

24. von Moos R, Body JJ, Egerdie B, et al. Pain and health-related quality of life in patients with advanced solid tumours and bone metastases: integrated results from three randomized, double-blind studies of denosumab and zoledronic acid. Support Care Cancer 21: 3497-507, 2013.

25. Kwon JH. Overcoming barriers in cancer pain management. J Clin Oncol. 32(16): 1727-33, 2014.

26. Thomason TE, McCune JS, Bernard SA, et al. Cancer pain survey: patient-centered issues in control. J Pain Symptom Manage 15: 275-284, 1998. 
International Journal of Hematology and Oncology

27. Harris K, Chow E, Zhang L, et al. Patients' and health care professionals' evaluation of health-related quality of life issues in bone metastases. Eur J Cancer 45: 2510-2518, 2009.

28. Oudard S, Banu E, Medioni J, e al. What is the real impact of bone pain on survival in patients with metastatic hormonerefractory prostate cancer treated with docetaxel? BJU Int 103: 1641-1646, 2009.

29. Campisi G, Fedele S, Fusco V, et al. Epidemiology, clinical manifestations, risk reduction and treatment strategies of jaw osteonecrosis in cancer patients exposed to antiresorptive agents. Future Oncol 10: 257-275, 2014.

30. Qian Y, Mohamed AF, Hauber AB, et al. Patients' and caregivers' preferences for bone metastases (BM) treatments in the United States. Value Health 16: A420, 2013.

31. Mohamed AF, Qian Y, Hauber AB, et al. Nurses' preferences for bone metastases treatments in the United States. Value Health 16: A430, 2013.

32. Arellano J, Hauber B, Mohamed A, et al. Physicians' preferences for bone metastases drug therapy in the United States. Value Health 18: 78-83, 2015.

33. Aoki Y, Nakagawa K, Hasezawa K, et al. Significance of informed consent and truth-telling for quality of life in terminal cancer patients. Radiat Med 15: 133-135, 1997.

34. Adenis A, Vennin P, Hecquet B. What do gastroenterologists, surgeons and oncologists tell patients with colon cancer? Results of a survey from the northern france area. Bull Cancer 85: 803, 1998.

35. Bowling A, Ebrahim S. Measuring patients' preferences for treatment and perceptions of risk. Qual Health Care 10 Suppl 1: i2-8, 2001.

36. Jahng KH, Martin LR, Golin CE, DiMatteo MR. Preferences for medical collaboration: patient-physician congruence and patient outcomes. Patient Educ Couns 57: 308-314, 2005.

\section{Correspondence}

Francesca GATTA

Amgen (Europe) $\mathrm{GmbH}$

Dammstrasse 23

$\mathrm{CH}-6301$

Zug / SWITZERLAND

e-mail: fgatta@amgen.com

Tel: (+41) 41- 3690428

Fax: (+41) 41- 3690400 